\title{
Estrogen regulation of TRPM8 expression in breast cancer cells
}

\author{
Dechen Chodon ${ }^{+1}$, Arnaud Guilbert ${ }^{+1}$, Isabelle Dhennin-Duthille1, Mathieu Gautier ${ }^{1}$, Marie-Sophie Telliez ${ }^{1}$, \\ Henri Sevestre1,2 and Halima Ouadid-Ahidouch*1
}

\begin{abstract}
Background: The calcium-permeable cation channel TRPM8 (melastatin-related transient receptor potential member 8) is over-expressed in several cancers. The present study aimed at investigating the expression, function and potential regulation of TRPM8 channels by ER alpha (estrogen receptor alpha) in breast cancer.

Methods: RT-PCR, Western blot, immuno-histochemical, and siRNA techniques were used to investigate TRPM8 expression, its regulation by estrogen receptors, and its expression in breast tissue. To investigate the channel activity in MCF-7 cells, we used the whole cell patch clamp and the calcium imaging techniques.

Results: TRPM8 channels are expressed at both mRNA and protein levels in the breast cancer cell line MCF-7. Bath application of the potent TRPM 8 agonist Icilin $(20 \mu \mathrm{M})$ induced a strong outwardly rectifying current at depolarizing potentials, which is associated with an elevation of cytosolic calcium concentration, consistent with established TRPM8 channel properties. RT-PCR experiments revealed a decrease in TRPM8 mRNA expression following steroid deprivation for 48 and 72 hours. In steroid deprived medium, addition of 17-beta-estradiol $\left(E_{2}, 10 \mathrm{nM}\right)$ increased both TRPM8 mRNA expression and the number of cells which respond to Icilin, but failed to affect the $\mathrm{Ca}^{2+}$ entry amplitude. Moreover, silencing ERa mRNA expression with small interfering RNA reduced the expression of TRPM8. Immuno-histochemical examination of the expression of TRPM8 channels in human breast tissues revealed an over-expression of TRPM8 in breast adenocarcinomas, which is correlated with estrogen receptor positive (ER+) status of the tumours.
\end{abstract}

Conclusion: Taken together, these results show that TRPM8 channels are expressed and functional in breast cancer and that their expression is regulated by ER alpha.

\section{Background}

Breast cancer is the most common form of cancer in women in industrialized countries. Clinical and experimental data have revealed that female steroid hormones play an essential role in the development of sporadic breast cancer [1]. For example, the steroid hormone 17- $\beta$ estradiol $\left(\mathrm{E}_{2}\right)$ is involved in the regulation of growth and differentiation of malignant breast epithelial cells [2]. The predominant biological effect of $\mathrm{E}_{2}$ is mediated through its interaction with two intracellular estrogen receptors (ER $\alpha$ and ER $\beta$ ), ER $\alpha$ being strongly expressed in $80 \%$ of breast cancers [2-4]. ERs are ligand-dependent transcrip-

* Correspondence: ha-sciences@u-picardie.fr

1 Laboratoire de Physiologie Cellulaire et Moléculaire, JE "2530: Canaux ioniques dans le cancer du sein", Faculté des Sciences, Université Picardie Jules Vernes, 33 rue Saint Leu, 80000, Amiens, France

+ Contributed equally

Full list of author information is available at the end of the article tion factors controlled by $E_{2}$, and they regulate the expression of many genes [1-5] including potassium [6], calcium $[7,8]$ and TRP (transient receptor potential) channels $[9,10]$.

Recently, TRP channels have emerged as new channels implicated in carcinogenesis [11-14]. In our laboratory, we have previously shown that TRPC6 (canonical-related TRP member 6) channels are over-expressed and functional in breast cancer [15]. More recently, we have shown that TRPM7 (melastatin-related TRP member 7) is involved in breast cancer cell proliferation [16]. In addition, TRPM8 (melastatin-related TRP member 8) channel is found to be over-expressed in several primary tumours including colon, lung, skin, and prostate cancer [17]. TRPM8 channel is a $\mathrm{Ca}^{2+}$-permeable cation channel which is stimulated by temperatures below $28^{\circ} \mathrm{C}$ and by the cooling agents Menthol and Icilin [18,19]. 
It is well established that TRPM8 channel expression is regulated by androgens. Indeed, the androgen regulation of TRPM8 expression was reported in prostate cancer and putative androgen receptor response elements were identified in the TRPM8 gene [20-22]. Therefore, TRPM8 channels can be considered as a valuable prognostic marker in prostate cancer [23]. However, in breast cancer, TRPM8 function and regulation by $\mathrm{E}_{2}$ are unknown. Only a single report has mentioned the over-expression of TRPM8 mRNA in breast cancer [17].

It is now well established that breast cancer cell line MCF-7 expresses $E_{2}$ receptors $\left(E R^{+}\right)$, and that 17- $\beta$-estradiol increases its proliferation [24]. In the present study, we examined the expression and function of TRPM8 in the $\mathrm{ER}^{+}$human breast cancer cell line MCF-7. We also determined whether TRPM8 mRNA expression was regulated by estrogens. Finally, we investigated whether TRPM8 is over-expressed in human breast cancer tissues regarding their ER status.

\section{Methods}

\section{Cell culture and steroid depletion procedure}

MCF-7 cells were routinely cultured in Dulbecco's Modified Eagle's Medium (Lonza, Belgium) including $4.5 \mathrm{~g} / \mathrm{L}$ glucose and L-glutamine, supplemented with $5 \%$ fetal calf serum (FCS), and maintained at $37^{\circ} \mathrm{C}$ in a humidified atmosphere with $5 \% \mathrm{CO}_{2}$. For steroid depletion experiments, MCF-7 cells were seeded in 60-mm Petri dishes at a density of $6.10^{5}$ cells/dish and grown for $48 \mathrm{~h}$. Then, cells were grown in a medium in which the FCS was replaced with starvation medium (OFCS) or steroid-free medium $(5 \%$ dextran-coated charcoal-treated FCS (DCCFCS) for 24, 48 and $72 \mathrm{~h}$ prior to incubation with $\mathrm{E}_{2}$ $(10 \mathrm{nM})$ for 24 and $48 \mathrm{~h} \mathrm{E}_{2}$ (Sigma, France) was dissolved in ethanol, and final $E_{2}$ concentration was obtained by appropriate dilution. The dilution factor was $<1 / 100000$.

\section{Electrophysiological recording}

MCF-7 cells were seeded in 35-mm Petri dishes at a confluence of $8.10^{4}$ cells/dish. They were grown at $37^{\circ} \mathrm{C}$ in a humidified atmosphere of air/ $/ \mathrm{CO}_{2}$ for further $48 \mathrm{~h}$ before electrophysiological recordings. Dishes with attached cells were transferred to a continually perfused recording chamber and TRPM8 activity was recorded using the conventional patch clamp technique in the whole cell configuration. Patch pipettes were made using haematocrit capillaries (Hirschmann-Laborgerate, Germany. Patch pipettes of 3-5 $\mathrm{M} \Omega$ were filled with (in $\mathrm{mM}$ ): $\mathrm{CsCl}$ $145, \mathrm{NaCl} 8, \mathrm{MgCl}_{2}$ 2, EGTA 10, and HEPES 10 (pH was adjusted to 7.2 using $\mathrm{CsOH}$ ). External solution for patchclamp recordings contained (in $\mathrm{mM}$ ): $\mathrm{NaCl} 140, \mathrm{KCl} 5$, $\mathrm{CaCl}_{2} 2, \mathrm{MgCl}_{2}$ 2, HEPES 10, Glucose 5, and TEA-Cl 5
( $\mathrm{pH}$ was adjusted to 7.4 using $\mathrm{NaOH}$ ). Activation of TRPM8 currents was achieved by external application of $20 \mu \mathrm{M}$ Icilin. Current-Voltage relationship was obtained by linear $100 \mathrm{~ms}$ ramps from $-100 \mathrm{mV}$ to $+100 \mathrm{mV}$ from a holding potential of $-40 \mathrm{mV}$. Signals were captured using a Digidata 1200 converter and they were analysed using an Axopatch 200B in combination with pClamp 9 software (All from Molecular Devices, Sunnyvale, CA, USA). Traces were filtered at $5 \mathrm{kHz}$ and digitized at $10 \mathrm{kHz}$. Analyses were made using Clampfit 9 (Molecular Devices, Sunnyvale, CA, USA) and Microcal Origin 8.0 software (Microcal Software, Northampton, MA, USA). Experiments were performed at room temperature $\left(21^{\circ} \mathrm{C}\right)$.

\section{Calcium imaging}

Calcium imaging experiments, using Fura-2, have been carried out as previously described [25]. The extracellular solution contained (in $\mathrm{mM}$ ): $145 \mathrm{NaCl}, 5 \mathrm{KCl}, 5 \mathrm{CaCl}_{2}, 2$ $\mathrm{MgCl}_{2}, 10$ HEPES, and 5 glucose (pH adjusted to 7.4 by $\mathrm{NaOH}$ ). Icilin and thapsigargin (TG, Sigma Aldrich, France) were dissolved in DMSO. The dilution factor was $<1 / 1000$

\section{Reverse transcription and semi-quantitative PCR}

Total RNA extraction and reverse transcription of RNA was carried out as previously described [15]. Sense and antisense PCR primers specific to TRPM8 channels (sense: 5'-TCTACGAGCCCTACCTG-3', antisense: 5'CACCGTGTAGCCAAAC-3'), ER $\alpha$ (sense: 5'-AGGTGTACCTGGACAGCAGCAAG-3', antisense: 5'-TCTAGAAGGTGGACCTGATCATG-3'), and $\beta$-actin (sense: 5'-CAGAGCAAGAGAGGCATCCT-3', antisense: 5'ACGTACATGGCTGGGGTG-3') were used. PCR reactions were carried out on a iCycler thermal cycler (Biorad, France) using the following parameters: denaturation at $94^{\circ} \mathrm{C}$ for $30 \mathrm{~s}$, annealing at $58^{\circ} \mathrm{C}$ (TRPM8 and $\beta$-actin) or $60^{\circ} \mathrm{C}(\mathrm{ER} \alpha)$ for $30 \mathrm{~s}$, and extension at $72^{\circ} \mathrm{C}$ for $40 \mathrm{~s} .23$ cycles for $\beta$-actin and 40 cycles for TRPM 8 and ER $\alpha$ primers were performed, followed by an extension at $72^{\circ} \mathrm{C}$ for $5 \mathrm{~min}$. PCR products were analyzed by gel electrophoresis and visualized by ethidium bromide staining. PCR products were quantified using Quantity One software (Biorad, France) and results are expressed as the ratio of ER $\alpha$ or TRPM8 on $\beta$-actin referent gene.

\section{Small Interfering (si) RNA cell transfection}

MCF-7 cells were transfected as previously described [26] using $2 \mu \mathrm{g}$ ER $\alpha$ siRNA (SiER $\alpha$ ) on target plus smart pool L-003401-00-0005 human ESR1 (Dharmacon, USA). Control experiments were performed by transfecting $2 \mu \mathrm{g}$ siRNA (SiControl) which does not target any known gene (D-001210-01-20, Dharmacon, USA). 


\section{Immunoprecipitation and Western Blotting}

MCF-7 cells were lysed in RIPA buffer (Triton X-100 1\%, sodium deoxycholate $1 \%, \mathrm{NaCl} 150 \mathrm{mM}$, Tris $\mathrm{HCl} 50 \mathrm{mM}$ pH 7.4, Sigma P8340 inhibitors cocktail, EDTA $2 \mathrm{mM}$, sodium orthovanadate $0.5 \mathrm{mM}$ ). Human colon cancer tissue proteins were extracted in the WCE buffer (Whole Cell Extract: $\mathrm{NaCl} 150 \mathrm{mM}$, Tris $\mathrm{HCl} 50 \mathrm{mM}$ pH7.5, NP40 1\%, Sigma P8340 inhibitors cocktail, SDS 0.1\% and sodium orthovanadate $1 \mathrm{mM}$ ) using a Polytron homogenizer (PRO-200, Fisher Bioblock Scientific). Equal amount of each protein sample $(30 \mu \mathrm{g})$ were separated by electrophoresis on SDS-PAGE and blotted onto nitrocellulose membrane (GE Healthcare). Blots were incubated as indicated with antibodies raised against TRPM8 (Abcam, 1/500) and $\beta$-actin (Santa Cruz, 1/2000) proteins. The blots were developed with the enhanced chemiluminescence (ECL) system (Bio-rad) using specific peroxidase-conjugated anti-IgG antibodies.

Immunoprecipitation experiments were performed on $1 \mathrm{mg}$ of protein sample from MCF-7 cells. Lysates were precleared $30 \mathrm{~min}$ with $50 \mu \mathrm{l}$ of protein G- and A-agarose beads. Supernatants were incubated overnight at $4^{\circ} \mathrm{C}$ with $1 \mu \mathrm{g}$ of TRPM8 antibody (Abcam) and then incubated with protein G- and A-agarose beads for $30 \mathrm{~min}$. Beads were washed three times with RIPA buffer and resuspended in SDS loading buffer before electrophoresis.

\section{Immuno-histochemistry}

Tumour and non-tumour tissue samples were selected by pathologists from fresh specimens and embedded in paraffin until analysis. Surgical consent forms were signed by the patients to allow the use of a portion of the cancerous tissue for research purposes. Samples were considered as $\mathrm{ER}^{+}$when $\mathrm{ER} \alpha$ was expressed. ER $\alpha$ immuno-histochemical staining $\left(\mathrm{ER}^{+}\right.$or $\left.\mathrm{ER}^{-}\right)$and tumour grade were evaluated by the pathologists in routine examination. The Scarff, Bloom and Richardson (SBR) histopronostic grading system is based on cell differentiation, nuclear polymorphism and mitotic activity: Grade I (welldifferentiated), Grade II (moderately-differentiated) and Grade III (poorly-differentiated).

TRPM8 immuno-histochemical studies were performed as previously described [15] using the indirect immuno-peroxidase staining technique on paraffinembedded material with a Ventana ES automatic analyzer (Ventana Medical Systems) and with a haematoxylin counterstain. Briefly, after blocking the endogenous peroxidase by the I-View Inhibitor (Ventana), sections were stained with an anti-TRPM8 antibody (Abcam, 1/1500), incubated with biotinylated anti-rabbit IgG (I-View Biotin Ig, Ventana) and exposed to streptavidine-peroxidase complex (I-View SA-HRP, Ventana). DAB $/ \mathrm{H}_{2} \mathrm{O}_{2}$ was used as chromogen and the slides were then examined under optical microscopy. Micrograph acquisition was performed by a camera connected to a Zeiss microscope equipped with a $x 20$ objective lens. Immuno-staining levels in the tumour tissue were determined by subjective visual scoring of the brown stain, and compared to the non tumoral tissue. Scoring levels were: $0=$ absence of staining; 1 = weak staining intensity (equal to normal tissue); 2 = moderate; $3=$ strong staining intensity. For the quantitative analysis, we report the percentage of cases presenting an over-expression of TRPM8 (scores 2 and 3).

All experiments on human tissues were approved by the Comité Consultatif de Protection des Personnes dans la Recherche Biomédicale de Picardie (CCPPRB), Amiens, France.

\section{Statistics}

Results are expressed as means \pm SEM. Unpaired Student $t$-tests were used for mRNA expression levels analysis. $\chi^{2}$ tests were used to estimate the significance between the effects of Icilin on the $\mathrm{Ca}^{2+}$ signal in $\mathrm{E}_{2}$ treated cells, and also to estimate the correlation between TRPM8 overexpression and adenocarcinomas ER status. Differences were considered significant when $\mathrm{p}<0.05$.

\section{Results}

\section{Evidence of functional TRPM8 channels in MCF-7 breast cancer cell line}

In order to examine whether TRPM8 channels are expressed in MCF-7 cells, RT-PCR and Western Blotting experiments were carried out (Fig. 1). We detected TRPM8 mRNA in MCF-7 cells, and in human colon cancer tissue which was used as a positive control (Fig. 1A). TRPM8 proteins were also observed in human colon cancer tissue and in a lesser extent in MCF-7 cells (Fig. 1B, lanes 1-2). Immunoprecipitation experiments using the same Abcam antibody confirmed the presence of TRPM8 proteins in MCF-7 cells (Fig. 1B, lane 3).

Whole cell currents were elicited by a $100 \mathrm{~ms}$ linear ramp from $-100 \mathrm{mV}$ to $+100 \mathrm{mV}$ from a holding potential of $-40 \mathrm{mV}$ (Fig. 2A, insert: upper panel), and were recorded at steady state $2 \pm 1$ minutes after the patch rupture. After $3 \pm 1$ minutes, cells were perfused with a solution containing $20 \mu \mathrm{M}$ of Icilin, the potent activator of TRPM8. Icilin activated a "noisy" non-selective current with a strong outward rectification (Fig. 2A). The current-density recorded in the presence of Icilin in the bath was markedly higher than before Icilin perfusion (43.42 \pm $12.60 \mathrm{pA} / \mathrm{pF}$ vs $5.94 \pm 1.77 \mathrm{pA} / \mathrm{pF}$ at $+100 \mathrm{mV})$. The reversal potential was $8.29 \pm 4.30 \mathrm{mV}$ in the presence of Icilin. However, Icilin induced a response in only $4 / 14$ cells $(28.6 \%$ of all the cells tested). Fig. 2A (insert, lower panel) shows the Icilin-activated current which is calculated by substracting the control current from the current recorded after Icilin application. 
A.

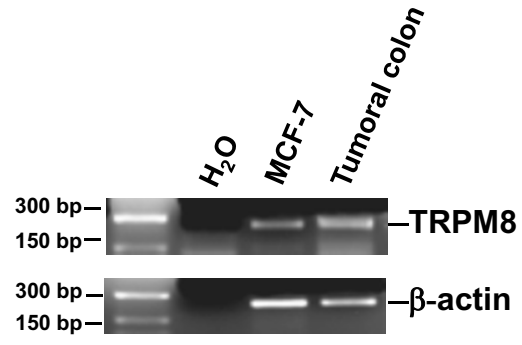

B.

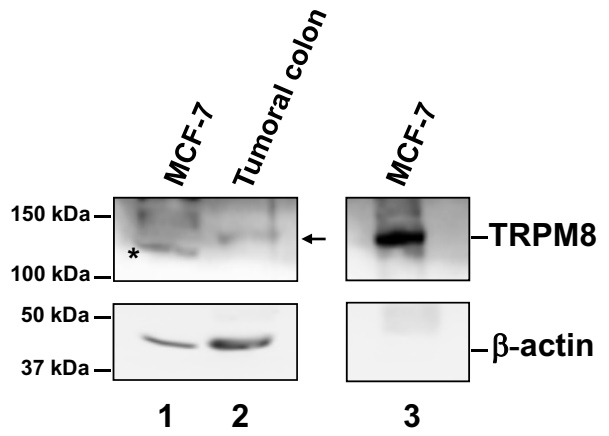

Figure 1 Analysis of TRPM8 mRNA and protein expression in MCF-7 cells. (A) RT-PCR analysis of human TRPM8 transcripts expression in MCF-7 cells on three independent cell lysates. Human colon extract was used as positive control for the detection of TRPM8. (B) Western blot analysis of TRPM8 proteins were performed on total lysate (lanes 1-2) of two independent cell extracts, or after immunoprecipitation experiment (lane 3). The arrow indicates a TRPM8 band, and $\left({ }^{*}\right)$ a non specific band.

To further characterize TRPM8 channels in MCF-7 cells, calcium imaging experiments were performed. Perfusion of Icilin at a concentration of $20 \mu \mathrm{M}$, in an external solution containing $5 \mathrm{mM} \mathrm{Ca}^{2+}$ caused a sustained elevation of cytoplasmic calcium concentration $\left[\mathrm{Ca}^{2+}\right]_{\mathrm{c}}$ (Fig. $2 \mathrm{~B})$. The proportion of responsive cells was only $32.16 \%$ of cells tested (64/199 of all the cells tested). TRPM8 protein can be present in the plasma membrane and in the endoplasmic reticulum of human prostate $\mathrm{LNCaP}$ cancer cell line [20]. Moreover, high concentrations of menthol in the absence of extracellular $\mathrm{Ca}^{2+}$ caused a small but significant increase in intracellular $\mathrm{Ca}^{2+}$ in LNCaP cells [20]. To test whether TRPM8 channels are functional at endoplasmic reticulum (ER), cells were perfused with $20 \mu \mathrm{M}$ Icilin in the absence of external $\mathrm{Ca}^{2+}$. In this condition, Icilin had no effect, while application of the most potent selective SERCA inhibitor Thapsigargin $(1 \mu \mathrm{M})$, which is often used to induce $\mathrm{Ca}^{2+}$ release from endoplasmic reticulum, increased intracellular $\mathrm{Ca}^{2+}$ in MCF-7 cells (Fig. $2 \mathrm{C}, \mathrm{n}=20$ ). Taken together, these results show that MCF7 cells express functional TRPM8 channels at the plasma
A.

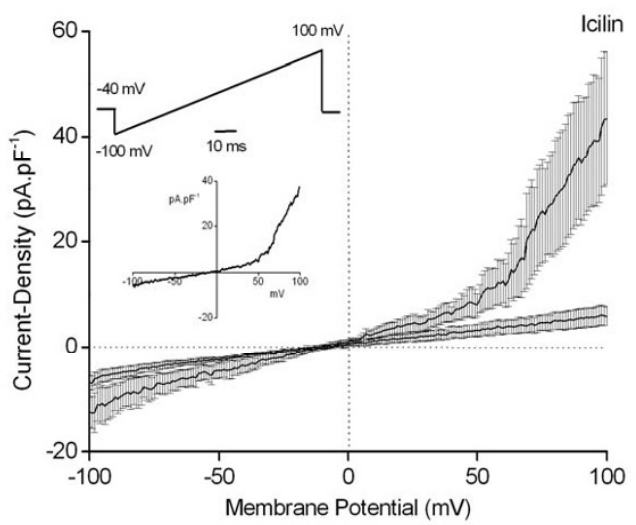

B.

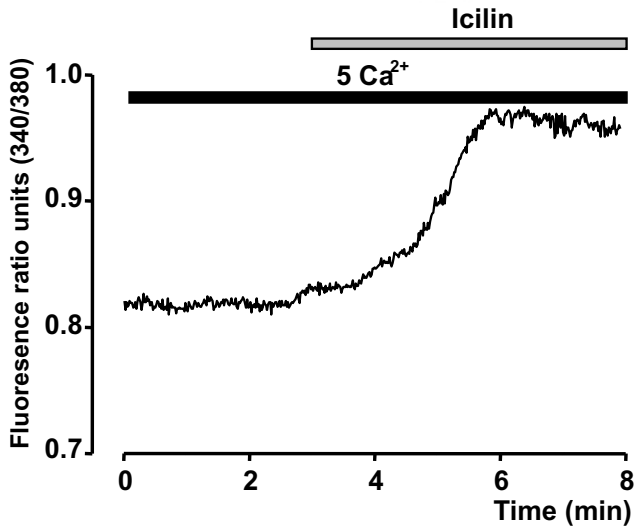

C.

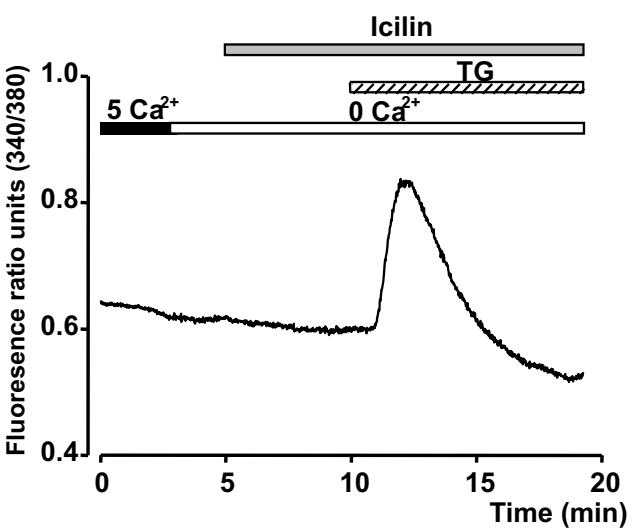

Figure 2 Icilin activated functional plasma membrane TRPM8 channel in MCF-7 breast cancer cell line. (A) Averaged I-V relationship of membrane current-densities in MCF-7 cells before and after application of Icilin $(20 \mu \mathrm{M})$ in the bath $(n=4)$. Upper panel represents the patch-clamp protocol and lower panel the Icilin-activated current. Whole cell currents were elicited by a $100 \mathrm{~ms}$ linear ramp from - $100 \mathrm{mV}$ to $+100 \mathrm{mV}$ from a holding potential of $-40 \mathrm{mV}$. (B) Average timecourse of $\left[\mathrm{Ca}^{2+}\right]_{C}$ variation measured as fluorescence at $340 / 380 \mathrm{~nm}$ ratio $(n=11)$. (C) Average time-course of $\left[\mathrm{Ca}^{2+}\right]_{C}$ changes $(n=20)$ during perfusion of $20 \mu \mathrm{M}$ Icilin and $1 \mu \mathrm{M}$ TG in the absence of extracellular $\mathrm{Ca}^{2+}$. 
membrane, and not at the endoplasmic reticulum membrane.

\section{7- $\beta$ estradiol enhanced TRPM8 expression in a steroid- deprived MCF-7 cells}

In order to determine whether the human TRPM8 was regulated by estrogens, we cultured MCF-7 cells in starved medium (0 FCS) or steroid-free medium (5\% dextran-coated charcoal-treated FCS (DCCFCS). Incubation of MCF-7 cells in DCCFCS induced a significant decrease in TRPM8 mRNA level by $76 \pm 8.4 \%$ of the control for 48 $h$ and $71.1 \pm 6.8 \%$ of the control for $72 \mathrm{~h}$ ( $\mathrm{p}<0.01$, Fig. $3 \mathrm{~A})$. As $17-\beta$ estradiol $\left(\mathrm{E}_{2}\right)$ is known to be the main physiological steroid in the breast, we studied the effects of adding $\mathrm{E}_{2}$ on TRPM8 expression in MCF-7 cells cultured under steroid-free conditions. After incubation in DCCFCS medium for $48 \mathrm{~h}$, MCF-7 cells were stimulated with $\mathrm{E}_{2}(10 \mathrm{nM})$ for $24 \mathrm{~h}$ and $48 \mathrm{~h}$. TRPM8 mRNA expression increased after $24 \mathrm{~h}(219.4 \pm 6.7 \%$ of control, $\mathrm{p}<$ $0.05)$ and $48 \mathrm{~h}(298.3 \pm 30.2 \%$ of control, $\mathrm{p}<0.01)$ of incubation with $\mathrm{E}_{2}$ (Fig. 3Ba). We observed similar results using OFCS medium with an increase of incubation with $\mathrm{E}_{2}$ after $24 \mathrm{~h}(350.1 \pm 123.3 \%$ of control) and $48 \mathrm{~h}(303.6 \pm$ $76.7 \%$ of control, $\mathrm{p}<0.05$ ) (Fig. 3Bb).

We then investigated the consequences of the $\mathrm{E}_{2}$ treatment on the $\mathrm{Ca}^{2+}$ signal induced by Icilin. Fig. $3 \mathrm{C}$ showed that after $48 \mathrm{~h}$ starvation, stimulation of MCF-7 cells with $\mathrm{E}_{2}(10 \mathrm{nM})$ for $24 \mathrm{~h}$ failed to affect both the number of cells responding to Icilin (48/205 in OFCS vs. 66/299 in $\left.0 F C S+E_{2}\right)$, and the amplitude of $\mathrm{Ca}^{2+}$ entry induced by Icilin $(\Delta \mathrm{R}=0.16 \pm 0.02, \mathrm{n}=48$ in 0FCS vs. $\Delta \mathrm{R}=0.15 \pm$ $0.02, \mathrm{n}=66$ in $0 \mathrm{FCS}+\mathrm{E}_{2}$ ). However, $\mathrm{E}_{2}$ treatment for $48 \mathrm{~h}$ increased the number of cells which respond to Icilin (47/ 388 in 0 FCS vs. $103 / 437$ in $0 F C S+E_{2}, p<0.001$, Fig. $3 C$ ), without a significant change in the amount of Icilininduced $\mathrm{Ca}^{2+}$ entry $(\Delta \mathrm{R}=0.14 \pm 0.01, \mathrm{n}=47$ in 0FCS vs. $\Delta \mathrm{R}=0.16 \pm 0.01, \mathrm{n}=103$ in $0 \mathrm{FCS}+\mathrm{E}_{2}$, Fig. $\left.3 \mathrm{C}\right)$.

\section{TRPM8 expression is regulated by ERa in human MCF-7 cells and correlated with ER status in breast adenocarcinomas}

The dependence of TRPM8 expression on the presence of ER $\alpha$ was studied using small interfering RNA to knockdown ER $\alpha$. After siRNA-ER $\alpha$ transfection, MCF-7 cells were cultured in complete medium for $72 \mathrm{~h}$. RT-PCR experiments confirmed that ER $\alpha$ was reduced by $44 \pm$ $7.5 \%$ of the control $(\mathrm{p}<0.01)$ and that TRPM8 mRNA expression decreased by $47 \pm 5.5 \%$ of the control ( $\mathrm{p}<$ 0.001) (Fig. 4).

We then examined the expression of TRPM8 channels in human tumoral and adjacent non-tumoral breast tissues. Immuno-histochemical study showed a stronger
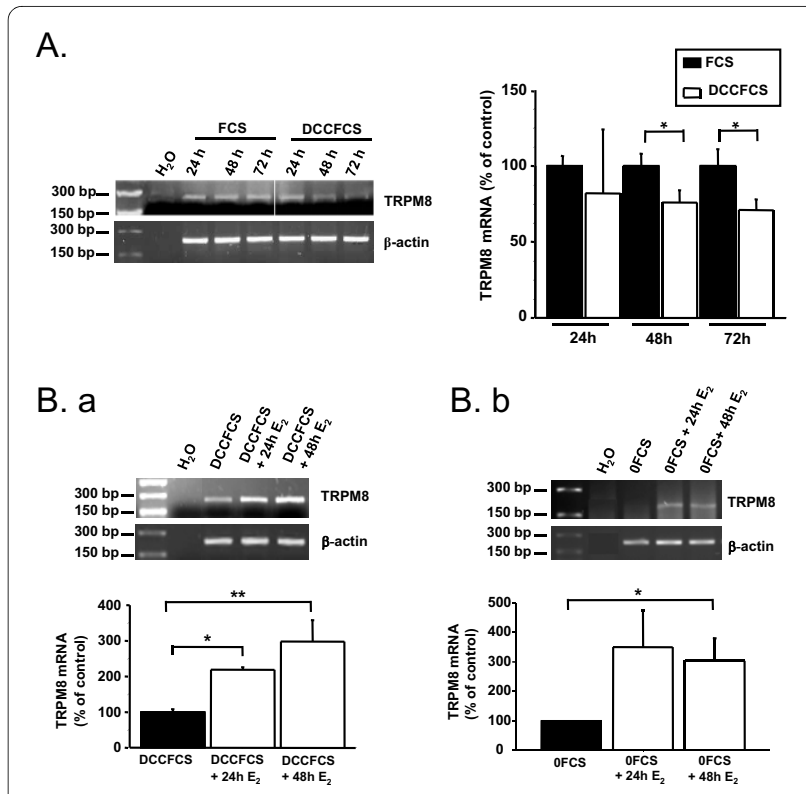

C.
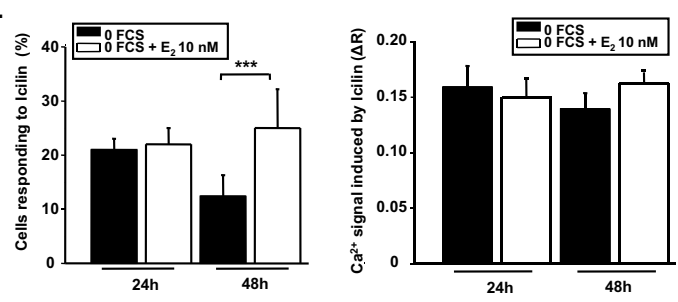

Figure 3 TRPM8 mRNA expression is under hormonal control. (A) Upper panel: agarose gel showing TRPM8 mRNA expression in MCF-7 cells which were incubated in steroid-free FCS medium (DCCFCS) for 24,48 and $72 \mathrm{~h}$. Lower panel: histogram showing a decrease of TRPM8 mRNA expression in DCCFCS medium ${ }^{*}, p<0.05$, three independent experiments). (B. a) Upper panel: a representative experiment showing TRPM8 mRNA expression in MCF-7 cells which were incubated in DCCFCS medium for $48 \mathrm{~h}$ prior to $\mathrm{E}_{2}(10 \mathrm{nM})$ application for 24 and $48 \mathrm{~h}$. Lower panel: histogram showing that $E_{2}$ increased TRPM8 mRNA expression (*, $p<0.05$, ${ }^{*}, p<0.01$, four independent experiments). (B. b) Upper panel shows an agarose gel representative of the effect of $E_{2}$ on TRPM8 expression. MCF-7 cells were growing in OFCS medium for $48 \mathrm{~h}$ prior to added $\mathrm{E}_{2}(10 \mathrm{nM})$ for $24 \mathrm{~h}$ and $48 \mathrm{~h}$. Lower panel: histogram showing that $E_{2}$ increased TRPM 8 mRNA levels ( ${ }^{*}, p<0.05$, three independent experiments). TRPM 8 mRNA levels are expressed as the ratio of TRPM 8 on $\beta$-actin referent gene. (C) Histograms showing the average of cells sensitive to Icilin (left panel) and the average of the amplitude of Icilin-induced $\mathrm{Ca}^{2+}$ entry (right panel) in MCF-7 cells -incubated in OFCS for $48 \mathrm{~h}$ prior to $\mathrm{E}_{2}(10 \mathrm{nM})$ application for 24 and $48 \mathrm{~h}(* * *, \mathrm{p}<$ 0.001 , three independent experiments)

cytosolic TRPM8 staining in cancerous epithelial cells (Fig. 5B) than in their non-tumoral counterpart (Fig. 5A). Statistical analysis revealed that the over-expression of TRPM8 in tumoral tissues was observed in $65.4 \%$ of the 26 ductal adenocarcinomas tested. To confirm ER $\alpha$ regulation of TRPM8 in a physiological context, we studied 
A.

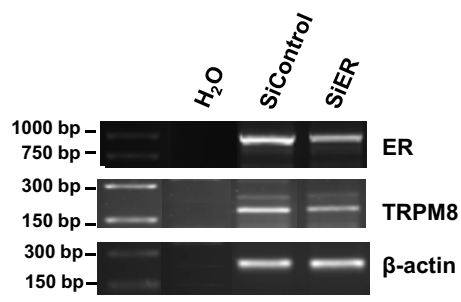

B.

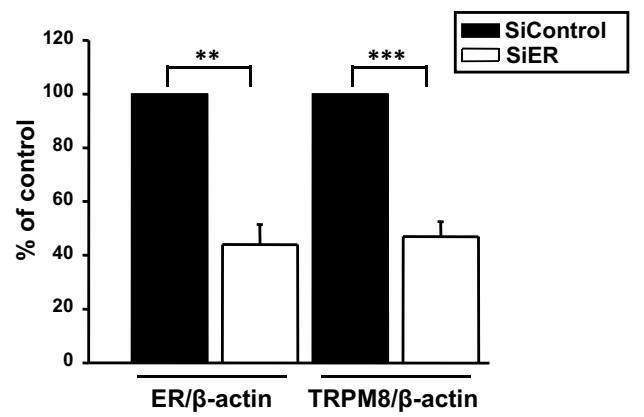

Figure 4 Silencing ERa reduced TRPM8 mRNA expression. (A) Agarose gel showing ERa and TRPM8 mRNAs expression in MCF-7 cells $72 \mathrm{~h}$ after transfection with SiERa. (B) Histogram showing that ERa silencing reduced TRPM8 mRNA expression (**, $p<0.01$, ${ }^{* * *}, p<0.001$, three independent experiments). TRPM 8 and ERa mRNA levels are expressed as the ratio of TRPM8 or ERa on $\beta$-actin referent gene.

the correlation between the over-expression of TRPM8 and ER $\alpha$ expression on breast cancer tissues samples. We found that TRPM8 over-expression was observed in $77.8 \%$ of the ER $\alpha$ positive tumours and in $37.5 \%$ of the $\mathrm{ER} \alpha$ negative tumours $(\mathrm{p}<0.05$, Table 1$)$, suggesting an association between TRPM8 expression and $\mathrm{ER}^{+}$status. Because one of the parameters used in the SBR grading system is the cell differentiation, we investigated whether the TRPM8 expression varied with tumour grades. Our results show that in the $\mathrm{ER}^{+}$adenocarcinomas which over-expressed TRPM8, 42.8\% (6/14) were grade I, $42.8 \%$ $(6 / 14)$ were grade II and $14.2 \%(2 / 14)$ were grade III.
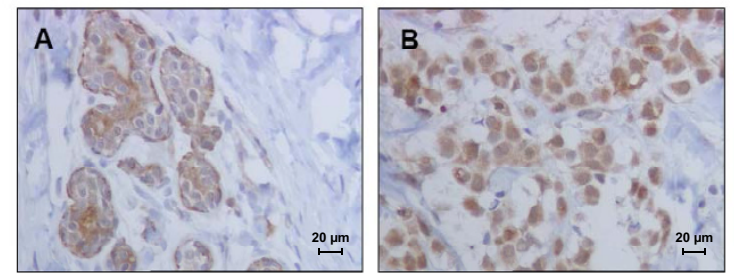

Figure 5 Over-expression of TRPM8 in breast adenocarcinomas. Immuno-histochemical staining using a specific anti-TRPM8 antibody in non tumoral (A) and breast cancer tissues (B). (Scale bar: $20 \mu \mathrm{m}$ ).
These results suggest that the TRPM8 expression depending on the differentiation status.

\section{Discussion}

In this study, we demonstrate that: 1) MCF-7 breast cancer cell line expressed a classical Icilin-sensitive channel, 2) Icilin induced also an increase of intracellular $\mathrm{Ca}^{2+}$ that was mediated by endogenous plasma membrane TRPM8 activation, 3) only $30 \%$ of cells under investigation respond to Icilin, 4) expression of TRPM8 is regulated by estrogens, and 5) the over-expression of TRPM8 in breast adenocarcinomas is correlated with $\mathrm{ER}^{+}$status.

Functional TRPM8 channels have been clearly characterized in over-expression systems $[18,19]$, in human cancer epithelial LNCaP cell line [20], and in primary culture of prostate epithelium cancer (PrPCa) cells [27]. Both cold and Menthol activated an inward current in LNCaP cell line [28], while Icilin activated a classical outwardly rectified TRPM8-current in PrPCa cells [22,27]. In MCF7 cells, application of the super-cooling agent Icilin, which is $\sim 200$-fold more potent than menthol, activated both an outwardly rectifying current and an elevation of cytoplasmic $\mathrm{Ca}^{2+}$ in a small fraction of cells ( $30 \%$ of all the cells tested). In cells responding to Icilin, the activated currents were characterized by an outward rectification and a reversal potential close to $0 \mathrm{mV}$ as described in the literature for plasma membrane TRPM8 evoked currents $[22,27]$. The small proportion of responding cells suggest that TRPM8 channels are not widely functionally expressed in the MCF-7 breast cancer line.

In LNCaP cells, two studies have reported dual localization of TRPM8 channels in the plasma membrane (PMTRPM8) and endoplasmic reticulum (ERTRPM8). Prevarskaya's group has demonstrated that the ${ }_{E R} T R P M 8$ is a truncated TRPM8 isoform which acts as an endoplasmic reticulum calcium releasing channel and which is not regulated by differentiation status $[27,29]$. In contrast, PM TRPM8 channels are regulated by the differentiation and androgen receptor status [27,29]. Indeed, ${ }_{\text {PM TRPM8 }}$ is fully expressed and functional in the early stages of well-differentiated androgen-dependent prostate cancer, and disappeared in metastasis profile when androgen receptors down-regulate. MCF-7 cell line was isolated from a non invasive adenocarcinoma, and retains several characteristics of differentiated mammary epithelium including the sensibility to estradiol via estrogen receptors and the capability of forming domes [30]. Moreover, when analysing the expression of TRPM8 according to breast cancer grades, we found that TRPM8 is rather over-expressed in grade I (well differentiated) and II (moderately differentiated) than in grade III (poorly differentiated). Taken together, we can suggest that in breast cancer, TRPM8 is functional at the plasma membrane 
Table 1: Correlation of TRPM8 over-expression with the ERa expression.

\begin{tabular}{cccc}
\hline & $\mathbf{n}$ & Over-expression (\%) & $\mathbf{X}^{\mathbf{2}}$ \\
\hline TRPM8 & & & $37.5 \%$ \\
ER- & 8 & $77.8 \%$ & $\mathbf{0 . 0 4 6 3}$ \\
ER+ & 18 &
\end{tabular}

The percentage of cases presenting an over-expression of TRPM8 according to the ERa expression was reported. A significant correlation

between TRPM8 expression and $E R^{+}$status was found $(* p<0.05)$.

and expressed in the early primitive breast cancers presenting a well-differentiated status.

Several studies have provided evidence of a pronounced TRPM8 expression in human tumours including prostate cancer, melanoma, lung cancer, colorectal adenocarcinoma and breast cancer $[17,22,31]$. Our results show, for the first time, that TRPM8 protein is overexpressed in human breast adenocarcinomas and that this over-expression is specifically correlated with ER $\alpha$ expression. Furthermore, in ER ${ }^{+}$MCF-7 cell line, TRPM8 expression is regulated by estrogens. Indeed, either ER expression silencing or $\mathrm{E}_{2}$ deprivation led to a reduction in TRPM8 mRNA expression, and application of $E_{2}$ increased TRPM8 mRNA. Moreover, stimulation of starved cells with $E_{2}$ increased the number of cells responding to Icilin without altering the amount of Icilininduced $\mathrm{Ca}^{2+}$ entry, suggesting that estrogens control the fraction of cells expressing TRPM8 channels rather than the amount of TRPM8 channel per cell. Taken together, these results suggest a hormonal-dependent regulation of TRPM8 expression in breast cancer. Regulation of TRPM8 by androgens in prostate cancer cells was suggested by Tsavaler et al [17] and confirmed in LNCaP cell line $[20,22]$. In LNCaP cells, the analysis of the TRPM8 gene resulted in the detection of 10 putative androgen responsive elements, one in the promoter region and the others in introns of the gene [20,22]. Altogether, we can suggest that TRPM8 gene expression is under steroid hormones regulation. However, in breast cancer, the regulation of TRPM8 gene expression by putative estrogen response elements needs further investigations.

\section{Conclusion}

In conclusion, we have shown that TRPM8 is expressed and functional in breast cancer MCF-7 cell line. Furthermore, we have provided evidence of ER mediated increase in TRPM8 mRNA expression. Finally, we have found a correlation between TRPM8 expression in tumour tissues and ER $\alpha$ expression.

The authors declare that they have no competing interests.
Authors' contributions

DC did the studies on the regulation of TRPM 8 by estrogens (E2 and SiRNA). AG and MG did the electrophysiological and the calcium imaging studies. ID-D did the immuno-histochemistry $(\mathrm{IHC})$, western blot, IP, and the conventional PCR studies. HS provided us with the human biopsies and allowed us to do the $\mathrm{IHC}$ in his laboratory. HO-A designed the studies and wrote the manuscript. All authors have read and approved the final manuscript.

\section{Acknowledgements}

The authors are grateful to the anatomic pathology department of the University Hospital of Amiens for immuno-histochemical studies. We thank Dr Alexandre Loucif for his contribution to the manuscript and his technical assistance. We also thank Momar DIOUF for his contribution to the statistic analysis.

This research was supported by the Region Picardie, the Cancéropôle Nord Ouest, the Ministère de l'Education Nationale, and the Ligue contre le cancer.

\section{Author Details}

'Laboratoire de Physiologie Cellulaire et Moléculaire, JE "2530: Canaux ioniques dans le cancer du sein", Faculté des Sciences, Université Picardie Jules Vernes, 33 rue Saint Leu, 80000, Amiens, France and 2Service d'Anatomie

Pathologique, CHU Nord, Amiens, France

Received: 26 October 2009 Accepted: 19 May 2010

Published: 19 May 2010

\section{References}

1. Sommer S, Fuqua SA: Estrogen receptor and breast cancer. Semin Cancer Biol 2001, 11(5):339-352.

2. Platet N, Cathiard AM, Gleizes M, Garcia M: Estrogens and their receptors in breast cancer progression: a dual role in cancer proliferation and invasion. Crit Rev Oncol Hematol 2004, 51(1):55-67.

3. Rutqvist LE, Cedermark B, Fornander T, Glas U, Johansson H, Nordenskjold B, Rotstein S, Skoog L, Somell A, Theve T, et al:: The relationship between hormone receptor content and the effect of adjuvant tamoxifen in operable breast cancer. J Clin Oncol 1989, 7(10):1474-1484.

4. Osborne CK: Steroid hormone receptors in breast cancer management. Breast Cancer Res Treat 1998, 51(3):227-238.

5. Foster JS, Henley DC, Ahamed S, Wimalasena J: Estrogens and cell-cycle regulation in breast cancer. Trends Endocrinol Metab 2001, 12(7):320-327.

6. Diaz L, Ceja-Ochoa I, Restrepo-Angulo I, Larrea F, Avila-Chavez E, GarciaBecerra R, Borja-Cacho E, Barrera D, Ahumada E, Gariglio P, et al: Estrogens and human papilloma virus oncogenes regulate human ether-a-go-go-1 potassium channel expression. Cancer Res 2009, 69(8):3300-3307.

7. Bosch MA, Hou J, Fang Y, Kelly MJ, Ronnekleiv OK: 17Beta-estradiol regulation of the mRNA expression of T-type calcium channel subunits: role of estrogen receptor alpha and estrogen receptor beta. J Comp Neurol 2009, 512(3):347-358.

8. Marni F, Wang Y, Morishima M, Shimaoka T, Uchino T, Zheng M, Kaku T, Ono K: 17 beta-estradiol modulates expression of low-voltageactivated $\mathrm{Ca}(\mathrm{V}) 3.2 \mathrm{~T}$-type calcium channel via extracellularly regulated kinase pathway in cardiomyocytes. Endocrinology 2009, 150(2):879-888. 
9. Lee GS, Jeung EB: Uterine TRPV6 expression during the estrous cycle and pregnancy in a mouse model. Am J Physiol Endocrinol Metab 2007, 293(1):E132-138.

10. Bolanz KA, Hediger MA, Landowski CP: The role of TRPV6 in breast carcinogenesis. Mol Cancer Ther 2008, 7(2):271-279.

11. Nilius B: TRP channels in disease. Biochim Biophys Acta 2007, 1772(8):805-812.

12. Gkika D, Prevarskaya N: Molecular mechanisms of TRP regulation in tumor growth and metastasis. Biochim Biophys Acta 2009, 1793(6):953-958.

13. Bodding M: TRP proteins and cancer. Cell Signal 2007, 19(3):617-624

14. Prevarskaya N, Zhang L, Barritt G: TRP channels in cancer. Biochim Biophys Acta 2007, 1772(8):937-946.

15. Guilbert A, Dhennin-Duthille I, El Hiani Y, Haren N, Khorsi H, Sevestre H, Ahidouch A, Ouadid-Ahidouch H: Expression of TRPC6 channels in human epithelial breast cancer cells. BMC Cancer 2008, 8(1):125.

16. Guilbert A, Gautier M, Dhennin-Duthille I, Haren N, Sevestre H, OuadidAhidouch $\mathrm{H}$ : Evidence that TRPM7 is required for breast cancer cell proliferation. Am J Physiol Cell Physiol 2009, 297(3):C493-C502.

17. Tsavaler L, Shapero MH, Morkowski S, Laus R: Trp-p8, a novel prostatespecific gene, is up-regulated in prostate cancer and other malignancies and shares high homology with transient receptor potential calcium channel proteins. Cancer Res 2001, 61(9):3760-3769.

18. McKemy DD, Neuhausser WM, Julius D: Identification of a cold receptor reveals a general role for TRP channels in thermosensation. Nature 2002, 416(6876):52-58.

19. Peier AM, Mogrich A, Hergarden AC, Reeve AJ, Andersson DA, Story GM, Earley TJ, Dragoni I, McIntyre P, Bevan S, et al:: A TRP channel that senses cold stimuli and menthol. Cell 2002, 108(5):705-715.

20. Zhang L, Barritt GJ: Evidence that TRPM 8 is an androgen-dependent $\mathrm{Ca}^{2+}$ channel required for the survival of prostate cancer cells. Cancer Res 2004, 64(22):8365-8373.

21. Henshall SM, Afar DE, Hiller J, Horvath LG, Quinn DI, Rasiah KK, Gish K, Willhite D, Kench JG, Gardiner-Garden M, et al:: Survival analysis of genome-wide gene expression profiles of prostate cancers identifies new prognostic targets of disease relapse. Cancer Res 2003, 63(14):4196-4203.

22. Bidaux G, Roudbaraki M, Merle C, Crepin A, Delcourt P, Slomianny C, Thebault S, Bonnal JL, Benahmed M, Cabon F, et al:: Evidence for specific TRPM8 expression in human prostate secretory epithelial cells: functional androgen receptor requirement. Endocr Relat Cancer 2005, 12(2):367-382.

23. Zhang L, Barritt GJ: TRPM8 in prostate cancer cells: a potential diagnostic and prognostic marker with a secretory function? Endocr Relat Cancer 2006, 13(1):27-38.

24. Cheskis BJ, Greger JG, Nagpal S, Freedman LP: Signaling by estrogens. J Cell Physiol 2007, 213(3):610-617.

25. El Hiani Y, Ahidouch A, Roudbaraki M, Guenin S, Brule G, OuadidAhidouch $\mathrm{H}$ : Calcium-sensing receptor stimulation induces nonselective cation channel activation in breast cancer cells. J Membr Biol 2006, 211(2):127-137.

26. Borowiec AS, Hague F, Harir N, Guenin S, Guerineau F, Gouilleux F, Roudbaraki M, Lassoued K, Ouadid-Ahidouch H: IGF-1 activates hEAG $\mathrm{K}(+)$ channels through an Akt-dependent signaling pathway in breast cancer cells: role in cell proliferation. J Cell Physiol 2007, 212(3):690-701.

27. Bidaux G, Flourakis M, Thebault S, Zholos A, Beck B, Gkika D, Roudbaraki M, Bonnal JL, Mauroy B, Shuba Y, et al:: Prostate cell differentiation status determines transient receptor potential melastatin member 8 channel subcellular localization and function. J Clin Invest 2007, 117(6):1647-1657.

28. Thebault S, Lemonnier L, Bidaux G, Flourakis M, Bavencoffe A, Gordienko D, Roudbaraki M, Delcourt P, Panchin Y, Shuba Y, et al:: Novel role of cold/ menthol-sensitive transient receptor potential melastatine family member 8 (TRPM8) in the activation of store-operated channels in LNCaP human prostate cancer epithelial cells. J Biol Chem 2005, 280(47):39423-39435.

29. Prevarskaya N, Skryma R, Bidaux G, Flourakis M, Shuba Y: Ion channels in death and differentiation of prostate cancer cells. Cell Death Differ 2007, 14(7):1295-1304.

30. Soule HD, Vazguez J, Long A, Albert S, Brennan M: A human cell line from a pleural effusion derived from a breast carcinoma. J Nat/ Cancer Inst 1973, 51(5):1409-1416.
31. Slominski A: Cooling skin cancer: menthol inhibits melanoma growth. Focus on "TRPM8 activation suppresses cellular viability in human melanoma". Am J Physio/ Cell Physiol 2008, 295(2):C293-295.

\section{Pre-publication history}

The pre-publication history for this paper can be accessed here: http://www.biomedcentral.com/1471-2407/10/212/prepub

doi: 10.1186/1471-2407-10-212

Cite this article as: Chodon et al., Estrogen regulation of TRPM8 expression in breast cancer cells BMC Cancer 2010, 10:212

\section{Submit your next manuscript to BioMed Central and take full advantage of:}

- Convenient online submission

- Thorough peer review

- No space constraints or color figure charges

- Immediate publication on acceptance

- Inclusion in PubMed, CAS, Scopus and Google Scholar

- Research which is freely available for redistribution

Submit your manuscript at www.biomedcentral.com/submit
C Biomed Central 